\title{
Direct relationship of antepartum glucose control and fetal erythropoietin in human Type 1 (insulin-dependent) diabetic pregnancy
}

\author{
J.A. Widness ${ }^{1}$, K. A. Teramo ${ }^{4}$, G. K. Clemons ${ }^{3}$, P. Voutilainen ${ }^{4}$, U.-H. Stenman ${ }^{4}$, S. M. McKinlay ${ }^{2}$ and R. Schwartz $^{1}$ \\ From the Departments of ${ }^{1}$ Pediatrics and ${ }^{2}$ Community Medicine, Brown University, Providence, Rhode Island, ${ }^{3}$ Lawrence Berkeley \\ Laboratories, University of California, Berkeley, California, USA, and the ${ }^{4}$ Departments I and II of Obstetrics and Gynecology, \\ University of Helsinki, Helsinki, Finland
}

\begin{abstract}
Summary. In the present study the antepartum relationship between maternal diabetic glucose control and fetal hypoxaemia was examined in 44 Type 1 (insulin-dependent) diabetic and 23 non-diabetic control pregnancies. Maternal $\mathrm{HbA}_{1 \mathrm{c}}$ was used to assess maternal integrated blood glucose control while fetal metabolic control was evaluated by antepartum glucose, insulin, and C-peptide determinations in amniotic fluid at elective caesarean delivery. Fetal hypoxaemia was assessed indirectly by fetal umbilical vein plasma erythropoietin level at delivery. A prospectively developed statistical pathway model was used to examine the relationship of these variables. In applying forced stepwise multiple regression with this model, we observed in the diabetic subjects that mean maternal $\mathrm{HbA}_{1 \mathrm{C}}$ during the last month of pregnancy
\end{abstract}

correlated significantly with fetal umbilical venous erythropoietin at delivery $(r=0.57, p<0.001)$. Additional significant contributions to umbilical venous erythropoietin were found for amniotic fluid glucose and amniotic fluid insulin when these two independent variables were added in stepwise fashion $(p<0.01)$. We conclude that in diabetic pregnancy, antepartum control of maternal hyperglycaemia is a significant factor associated with fetal hypoxaemia. We speculate that this effect is mediated through perturbations which accelerate fetal metabolism and which is expressed by amniotic fluid levels of glucose and insulin.

Key words: Erythropoietin, $\mathrm{HbA}_{1 c}$, fetus, oxygenation, diabetes mellitus.
Although in recent years the outcome of diabetic pregnancies has dramatically improved, fetal and neonatal morbidity and mortality remain increased relative to normal pregnancies $[1,2]$. Some of the pathological features observed in offspring of these pregnancies have been shown to be associated with maternal hyperglycaemia (eg., respiratory distress syndrome, congenital malformations, and neonatal hypoglycaemia); others have not. Among the latter are the increased incidence of late gestation fetal death, antepartum and intrapartum fetal distress, and neonatal polycythaemia. We and others have speculated that these features of diabetic pregnancies have their origins in chronic and/or acute fetal hypoxaemia [3-5].

The purpose of the present study was to indirectly examine the antepartum relationship between chronic maternal hyperglycaemia and fetal oxygenation in Type 1 (insulin-dependent) diabetic pregnancies delivered by elective caesarean section before the confounding effect of labour [6]. To do so, we prospectively developed a hypothetical pathway model for statistical analyses in which chronic maternal hyperglycaemia was related to chronic fetal hypoxaemia through several intermediate steps. $\mathrm{HbA}_{1 \mathrm{C}}$ served as an indicator of chronic maternal glycaemia [7] and plasma erythropoietin (Ep) concentration was utilized to assess fetal oxygenation [8-10]. Amniotic fluid levels of glucose, insulin and C-peptide served as intermediary chronic indicators of fetal metabolism [11-13].

\section{Subjects and methods}

\section{Subjects}

After obtaining approval by the Ethical Committee at the University of Helsinki and after obtaining each patient's consent, control and Type 1 (insulin-dependent) diabetic subjects carrying singleton fetuses were studied at the Women's Hospital of the University Central Hospital of Helsinki. This population is relatively homogenous with respect to ethnic origin, socio-economic status, and prenatal care.

Forty-four Type 1 diabetic subjects, all of whom were clinically managed by one of the authors (KAT) were studied. Included were women from White's Classes B $(n=1), \mathrm{C}(n=8), \mathrm{D}(n=25)$, and $\mathrm{F}$ $(n=10)$. Although the goal of diabetic management of these women was to achieve normoglycaemia, this was not possible in all subjects. In addition to their diabetes, 18 of the $44(41 \%)$ women had pregnancies complicated by one or more high risk obstetrical factors, including pregnancy-induced hypertension $(n=14)$, chronic hypertension $(n=1)$, epilepsy $(n=3)$, and bronchiectasis $(n=1)$. Four of the 44 diabetic mothers $(9 \%)$ gave a history of cigarette smoking during pregnancy. All but one, however, smoked less than ten cigarettes a day. Primary indications for elective caesarean section with.) dt labour included repeat caesarean section $(n=5)$, advanced maternal diabetes (i.e., White Class D or F) $(n=36)$, maternal seizure disorder $(n=1)$, breech presentation $(n=1)$, and macrosomia $(n=1)$. None demonstrated evidence of antepartum fetal distress as assessed by daily fetal cardiotocographic monitoring during the last two weeks of pregnancy. The duration of gestation at delivery ranged from 228 to 278 days, and birth weights ranged from 1,830 to $5,090 \mathrm{~g}$ (Table 1 ). Thirteen of the 44 fetuses of diabetic mothers $(30 \%)$ were macrosomic (birth weight $>2 \mathrm{SD}$ above the mean) and 
Table 1. Demographic characteristics of the newborn infants

\begin{tabular}{lcc}
\hline & Control subjects & $\begin{array}{c}\text { Type 1 (insulin- } \\
\text { dependent) dia- } \\
\text { betic subjects }\end{array}$ \\
\hline Number of subjects & 23 & 44 \\
Gestational age (days) & $270 \pm 5.7$ & $260 \pm 9.4^{\mathrm{a}}$ \\
Birth weight (g) & $(253$ to 277$)$ & $(228$ to 278$)$ \\
Birth weight (z score) & $3444 \pm 402$ & $3681 \pm 742$ \\
& $(2880$ to 4270$)$ & $(1830$ to 5090$)$ \\
Maternal $\mathrm{HbA} \mathrm{AC}_{\mathrm{C}}$ & $0.07 \pm 0.94$ & $1.29 \pm 1.49^{\mathrm{a}}$ \\
(\% of total Hb) & not done & $6.60 \pm 0.99^{\mathrm{b}}$ \\
\end{tabular}

mean $\pm \mathrm{SD}$; ( ) range

a $p<0.001$ compared to control subjects (unpaired $t$ test); b $p<0.001$ one sample $t$ test $\left(\mathrm{HbA}_{1 \mathrm{C}}\right.$ for normal pregnant women $=5.4 \pm 0.6 \%[15]$ )

none were growth retarded (birth weight $<2 \mathrm{SD}$ below the mean) when compared to a Finnish reference population [14].

For comparison with the diabetic subjects, a group of 23 control pregnancies was simultaneously studied. Control women were included if they had no significant prior illness, no pregnancy-related complications, and no risk factor for gestational diabetes. Positive risk factors for the latter included obesity ( $>120 \%$ of ideal body weight), glycosuria, family history of diabetes, and birth of a previously large infant (birth weight $>2$ SD). Indications for elective caesarean section prior to delivery among control subjects included breech presentation $(n=6)$, repeat caesarean section $(n=15)$, fear of labour $(n=1)$, and benign ovarian tumour $(n=1)$. Additional selection criteria for this group included neonatal one and/or five min APGAR scores of 8 or above, birth weight within 2 SD of the mean, and a normal neonatal course. The duration of gestation at delivery in the control group ranged from 253 to 286 days, and birth weight ranged from 2,760 to $4,280 \mathrm{~g}$ (Table 1 ).

\section{Blood and amniotic fluid sampling}

Maternal blood was sampled for determination of $\mathrm{HbA}_{1 \mathrm{C}}$ at biweekly prenatal visits unless dictated otherwise by clinical circumstances. The total number of times $\mathrm{HbA}_{1 \mathrm{C}}$ was measured for each patient varied from 4 to 18 , depending on the frequency of her high risk clinic visits.

Blood and amniotic fluid were sampled in all pregnancies at the time of elective caesarean section. Amniotic fluid was sampled through the uterine wall or through the exposed fetal membranes less than two min prior to birth. There was no contamination with blood in any of the cases. Upon delivery a segment of the umbilical cord was doubly clamped before the infant's first cry and kept on wet ice until analysed or centrifuged for separation of plasma. Umbilical arterial blood was drawn into heparinized syringes for the measurement of $\mathrm{pH}$, and blood gases. This was accomplished within $15 \mathrm{~min}$ of delivery using a Corning $\mathrm{pH} /$ blood gas analyser Model $178 \mathrm{Hb}$ concentration was determined on a UV blood sample after which plasma was separated by centrifugation and stored at $-20^{\circ} \mathrm{C}$ prior to biochemical analysis.

\section{Laboratory measurements}

$\mathrm{Hb}_{\mathrm{lC}}$ was determined using an HPLC procedure in which the labile portion of $\mathrm{HbA}_{1 \mathrm{C}}$ is removed during haemolysis [15]. Using this method the mean $\mathrm{HbA}_{1 \mathrm{C}}$ in normal third trimester pregnant women has been found to be $5.44 \pm 0.57 \%$ (mean \pm SD) of total $\mathrm{Hb}$.

Glucose was analysed by a semi-automated glucose oxidase technique using a YSI Model 23 A Glucose Analyzer (Yellow Springs Instruments, Yellow Springs, Ohio, USA). Insulin was measured in a double antibody radioimmunoassay using ${ }^{125}$ I-A 14 -insulin and unla- belled human insulin standards (kindly provided by Eli Lilly, Indianapolis Ind., USA). Insulin antisera was obtained from Linco Research Inc. (Eureka, Mo, USA). To avoid inclusion of amniotic fluid insulin data in which the presence of high endogenous insulin antibody levels could influence the insulin assay results, amniotic fluid insulin antibody concentration was measured [16]. C-peptide determinations were made using commercially available RIA reagents (Serono Diagnostics, Boston, Mass., USA) or tyrosylated ${ }^{125} \mathrm{I}-\mathrm{C}$ peptide (Eli Lilly) and guinea pig C-peptide antisera (Linco). All determinations were performed within six months of sampling. Interassay coefficient of variation of the assay was $11 \%$.

Ep was measured in duplicate using a double antibody RIA on $100 \mu$ aliquots of plasma [17]. The intrassay coefficient for this assay is $6.49 .9 \%$ and its interassay coefficient is $8.8-13.2 \%$.

\section{Statistical pathway model}

The prospectively developed statistical pathway model of the diabetic pregnancy that we used linked maternal glycaemia with fetal hypoxaemia via a cascade of known and speculative pathophysiologic processes (Fig.1). The basis for this model was the knowledge that maternal hyperglycaemia results in fetal hyperglycaemia, which in late pregnancy stimulates the fetal endocrine pancreas to produce excessive amounts of insulin (and C-peptide) [1]. Maternal $\mathrm{HbA}_{1 \mathrm{C}}$ was used as an indicator of maternal glycaemia. This nonlabile, Amadori product of glucose and $\mathrm{Hb}$ has been shown to provide an integrated assessment of mean glucose concentration during the preceding four to six weeks [7]. Plasma Ep concentration was selected as the indicator of fetal oxygenation since Ep production in both the fetus and the adult is primarily mediated through fluctuations in tissue oxygenation [18]. Furthermore, since maternal Ep does not cross the placenta [8], fetal Ep concentration reflects fetal oxygenation. We have previously shown that fetal plasma levels of Ep increase rapidly after several hours of sustained hypoxaemia in which oxygen content is decreased by $30-40 \%$ [9]. During normoxaemia the plasma Ep half-life varies from 1.5-10 h [19-21].

Amniotic fluid levels of glucose, insulin, and C-peptide were chosen as indicators of fetal metabolic status since changes in these occur slowly i. e., hours to days $[11,12]$. Since plasma levels of glucose, insulin, and C-peptide are known to vary rapidly (i.e., min), they were not included in the analyses. Although it has not been conclusively shown in the human, there is animal evidence that fetal hyperglycaemia and/or hyperinsulinaemia results in fetal hypoxaemia secondary to increased oxygen consumption $[22,23]$. We did not attempt to make this model all-inclusive by measuring other variables associated with the pathogenesis of the diabetic pregnancy,

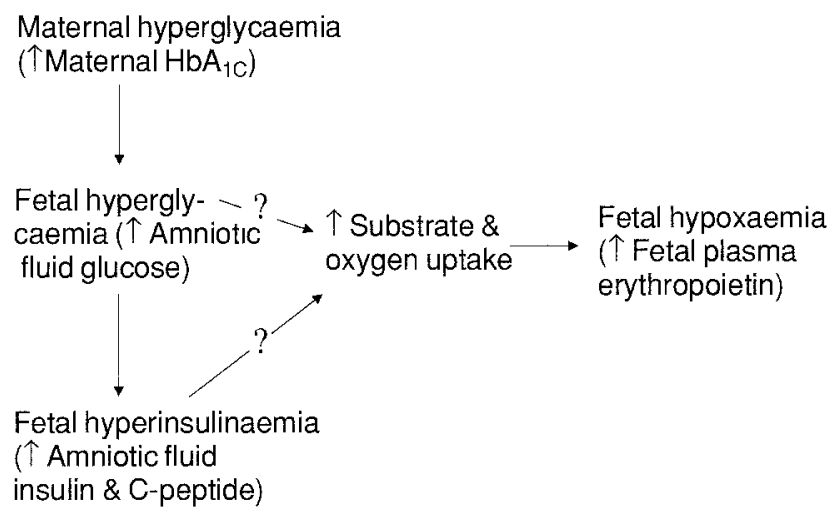

Fig.1. Statistical pathway model of fetal hypoxaemia in the diabetic pregnancy. Established physiologic interrelationships are indicated by the solid arrows while arrows with question marks indicate hypothetical relationships examined in the present study. Variables in parentheses are the measured variables of maternal glucose and fetal metabolic environment measured in the present study 
Table 2. Fetal biochemical and hormonal data at delivery

\begin{tabular}{lcc}
\hline & Control subjects & $\begin{array}{c}\text { Type 1(insulin- } \\
\text { dependent) dia- } \\
\text { betic subjects }\end{array}$ \\
\hline Number of subjects & 23 & 44 \\
Umbilical vein plasma & $23.8 \pm 9.5$ & $294 \pm 976^{\mathrm{a}}$ \\
erythropoietin (mU/ml) & $(9.8$ to 50.3$)$ & $(11$ to 6130$)$ \\
Amniotic fluid glucose & $1.03 \pm 0.58$ & $2.11 \pm 1.68^{\mathrm{a}}$ \\
(mmol/l) & $(0.39$ to 2.11$)$ & $(0.39$ to 8.56$)[43]$ \\
Amniotic fluid insulin & $48.4 \pm 25.6$ & $309 \pm 465^{\mathrm{a}}$ \\
(pmol/l) & $(13$ to 133$)[22]$ & $(40$ to 2,533$)[41]$ \\
Amniotic fluid & $325 \pm 142$ & $791 \pm 464^{\mathrm{a}}$ \\
C-peptide (pmol/l) & $(151$ to 647$)$ & $(167$ to 2004$)$ \\
\hline
\end{tabular}

mean $\pm \mathrm{SD} ;$ ( ) range. [ ] number of subjects, if different. ${ }^{a} p<0.001$ compared to control subjects (Mann-Whitney U Test)

Table 3. Fetal Hb, pH, blood gases, and base excess data at delivery

\begin{tabular}{|c|c|c|}
\hline & Control subjects & $\begin{array}{l}\text { Type } 1 \text { (insulin- } \\
\text { dependent) dia- } \\
\text { betic subjects }\end{array}$ \\
\hline Number of subjects & 23 & 44 \\
\hline $\begin{array}{l}\text { Umbilical vein } \\
\mathrm{Hb}(\mathrm{g} / \mathrm{l})\end{array}$ & $\begin{array}{c}146 \pm 15.9 \\
(125 \text { to } 185)[20]\end{array}$ & $\begin{array}{c}168 \pm 20.2^{\mathrm{a}} \\
(121 \text { to } 209)[38]\end{array}$ \\
\hline $\begin{array}{l}\text { Umbilical artery } \\
\mathrm{pH}\end{array}$ & $\begin{array}{c}7.30 \pm 0.049 \\
(7.20 \text { to } 7.41)[21]\end{array}$ & $\begin{array}{c}7.25 \pm 0.055^{\mathrm{a}} \\
(7.14 \text { to } 7.36)[39]\end{array}$ \\
\hline $\begin{array}{l}\text { Umbilical artery } \\
\mathrm{pO}_{2}\left(\mathrm{kP}_{\mathrm{a}}\right)\end{array}$ & $\begin{array}{c}2.27 \pm 0.71 \\
(1.18 \text { to } 3.59)[20]\end{array}$ & $\begin{array}{c}2.33 \pm 0.68 \\
(2.33 \text { to } 3.62)[39]\end{array}$ \\
\hline $\begin{array}{l}\text { Umbilical artery } \\
\mathrm{pCO}_{2}\left(\mathrm{kP}_{\mathrm{a}}\right)\end{array}$ & $\begin{array}{c}6.77 \pm 0.88 \\
(5.19 \text { to } 8.64)[21]\end{array}$ & $\begin{array}{c}7.69 \pm 1.00^{\mathrm{a}} \\
(5.56 \text { to } 9.58)[39]\end{array}$ \\
\hline $\begin{array}{l}\text { Umbilical artery } \\
\text { base excess (mmol/l) }\end{array}$ & $\begin{array}{l}-2.2 \pm 2.87 \\
(-11.4 \text { to }+1.5)[21]\end{array}$ & $\begin{array}{l}-3.1 \pm 2.77 \\
(-7.5 \text { to }+2.2)[39]\end{array}$ \\
\hline
\end{tabular}

such as those included in the "mixed nutrient" environment as detailed by Metzger and Freinkel [24].

\section{Statistical analysis}

Results were analysed using standard statistical procedures with a commercial statistical software package (Statview II, Abacus Concepts, Inc, Berkeley, Calif., USA). Contingency tables were used to examine group differences for noncontinuous variables. The diabetic and control groups were compared using the two-tailed $t$ test and the Mann-Whitney U-test as indicated. In order to adjust for skewness, Ep, insulin, and C-peptide values were transformed to their $\log _{10}$ equivalents. Simple and multiple linear regression were used to test for associations between study variables. In applying our hypothetical model, study variables were forced into multiple regression equations in the predetermined stepwise sequences detailed in Figure 1. Given the multiple testing of data, the conservative alpha level of significance chosen was $p<0.01$. Missing amniotic fluid glucose $(n=1)$ and insulin $(n=1)$ values in which anti-insulin antibody levels were $>3 \mathrm{SD}$ of control values $(n=3)$ were treated in the regression analyses by substituting the group specific mean value for the variable in question and adjusting the degrees of freedom downward [25].

\section{Results}

Significant differences between the offspring of control and diabetic groups were observed for gestational age and birth weight $\mathrm{z}$ score $(p<0.001)$ (Table 1$)$. Absolute birth weight, however, and APGAR score $\left(\chi^{2}=1.87, \mathrm{df}=5\right)$ were not different. In 20 of the 44 diabetic pregnancies $(45 \%)$ mean maternal $\mathrm{HbA}_{1 \mathrm{C}}$ level in the month prior to delivery was $>6.6 \%$ of total $\mathrm{Hb}$, i.e., $2 \mathrm{SD}$ above the mean of non-diabetic subjects $(p<0.001)$ [15]. UV Ep concentration and amniotic fluid levels of glucose, insulin, and C-peptide were higher in the fetuses of diabetic mothers than in the control group ( $p<0.001$; Table 2$)$. Whole blood UV $\mathrm{Hb}$ and $\mathrm{pCO}_{2}$ tension were higher and umbilical arterial $\mathrm{pH}$ lower among the fetuses of diabetic mothers $(p<0.001$; Table 3$)$. In contrast, umbilical arterial $\mathrm{pO}_{2}$ tension and base excess measured at the time of elective caesarean section were not significantly different between the two groups.

When fetal UV plasma Ep concentration was correlated with gestational age, there was no significant association found for either the control or diabetic groups. Although this finding differs from that of Thomas et al. [26] for Ep measured in umbilical plasma, the range of gestational ages in the present study was narrower with the majority of our infants delivered at or near term (Table 1).

Simple correlations of maternal $\mathrm{HbA}_{1 \mathrm{C}}$ with $\mathrm{UV} \mathrm{Hb}$ and with umbilical arterial $\mathrm{pH}, \mathrm{pO}_{2}, \mathrm{pCO}_{2}$, and base excess in the diabetic group were all non-significant. Similarly, when the control and diabetic groups were examined separately, there was no association of UV Ep concentration with any of these variables. When the control and diabetic groups was combined, however, there was a significant negative association of UV Ep concentration with $\mathrm{pH}(r=0.38, p<0.01, n=60)$ and a significant positive association with $\mathrm{pCO}_{2}$ tension $(r=0.36, p<0.01, n=60)$. There was no correlation of UV Ep concentration with $\mathrm{Hb}, \mathrm{pO}_{2}$, or base excess.

Using simple linear regression, there was a significant direct relationship of UV Ep concentration with the mean maternal $\mathrm{HbA}_{1 \mathrm{C}}$ measured the month preceding delivery $(r=0.57, p<0.0001)$ (Fig. 2). Categorization of mean $\mathrm{HbA}_{1 \mathrm{C}}$ data into discrete, monthly four week interval

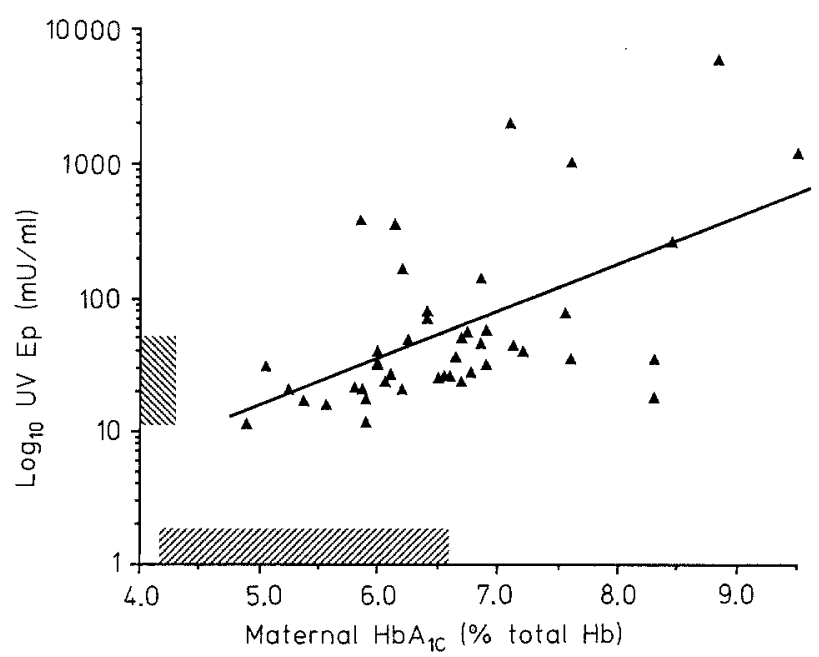

Fig. 2. Correlation of mean maternal $\mathrm{HbA}_{1 \mathrm{C}}$ during the last month prior to delivery with umbilical vein erythropoietin $(r=0.57$, $p<0.0001, \log _{10} \mathrm{y}=0.36 \mathrm{x}-0.62, \mathrm{SE}_{\mathrm{est}}=0.51$ ). The shaded area along the ordinate represents the standard range of UV Ep values for the 23 control subjects. The shaded area along the abscissa represents $\pm 2 \mathrm{SD} \mathrm{HbA}_{1 \mathrm{C}}$ values for a previously studied group of non-diabetic pregnant women [15] 
Table 4. Maternal $\mathrm{HbA}_{1 \mathrm{C}}$ and correlation coefficient of antepartum maternal $\mathrm{HbA}_{1 \mathrm{C}}$ and fetal plasma Ep

\begin{tabular}{llll}
\hline $\begin{array}{l}\text { Interval month } \\
\text { prior to delivery }\end{array}$ & $\begin{array}{l}\text { Number } \\
\text { of subjects }\end{array}$ & $\begin{array}{l}\text { Maternal } \\
\mathrm{HbA}_{1 \mathrm{C}} \\
(\% \text { tot } \mathrm{Hb})\end{array}$ & $\begin{array}{l}\text { Correlation coeffi- } \\
\text { cient of maternal } \\
\text { HbA }_{1 \mathrm{C}} \text { vs Log } \text { Lop }_{10} \text { Ep }\end{array}$ \\
\hline 1 & 44 & $6.6 \pm 1.0$ & $0.57^{\mathrm{a}}$ \\
2 & 44 & $6.9 \pm 1.4$ & 0.36 \\
3 & 42 & $6.8 \pm 1.0$ & 0.35 \\
4 & 41 & $6.9 \pm 1.0$ & 0.31 \\
5 & 41 & $6.8 \pm 1.0$ & $0.40^{\mathrm{b}}$ \\
\hline
\end{tabular}

mean $\pm \mathrm{SD}$

${ }^{\mathrm{a}} p<0.001 ; \mathrm{b} p<0.01$

blocks was done to permit a longitudinal antepartum assessment of the relationship of this variable with UV Ep concentration at delivery (Table 4). Despite fluctuations of $\mathrm{HbA}_{1 \mathrm{C}}$ among individual diabetic patients, mean monthly maternal $\mathrm{HbA}_{1 \mathrm{C}}$ levels did not change significantly during the last five months of pregnancy. Although at five months prior to delivery the relationship UV Ep with $\mathrm{HbA}_{1 c}$ barely reached our arbitrary level of significance $(p<0.01)$, this was not achieved during antepartum months 2 through 4.

To examine the effects of maternal diabetes exclusive of other potential confounding factors associated with fetal hypoxaemia, a subgroup of 28 of the 44 fetuses of diabetic mothers was examined separately. Excluded from this subgroup were pregnancies of women with hypertensive disease of pregnancy, bronchiectasis, and those whose cigarette consumption during pregnancy exceeded one-half pack per day. In this subgroup of fetuses of diabetic mothers a highly significant correlation of mean maternal $\mathrm{HbA}_{1 C}$ during the month before delivery was also found with UV Ep concentration $(r=0.62, p<0.001)$.

In the entire group of fetuses of diabetic mothers, amniotic fluid levels of glucose, insulin, and C-peptide were significantly correlated with UV Ep concentration $(p<0.01)$ (Fig. $3 \mathrm{a}-c)$. In addition, amniotic fluid glucose, insulin, and C-peptide levels were significantly correlated with one another $(p<0.01)$. This was in contrast to the control group in which there were no significant associations of UV Ep concentration with any of the fetal amniotic fluid variables.

Forced stepwise multiple regression was used to assess the contribution of the various individual maternal and fetal measurements to fetal hypoxia. The sequence of forcing the variables into the multiple regression equations was based on our statistical pathway model (Fig.1). The first of the two pathways examined was the two-step process which included maternal hyperglycaemia as the first step and fetal hyperglycaemia as the second. Amniotic fluid glucose made a significant additional contribution to the regression equations with UV Ep concentration as the outcome variable $\left(\mathrm{F}_{1,42}\right.$ to enter $=7.8, p<0.01$; multiple $r^{2}=0.44, p<0.0001$ ).

Since fetal hyperglycaemia is a known stimulus for fetal insulin secretion, the second possible pathway investigated with our model was that in which elevated amniotic fluid glucose is associated with increased amniotic fluid insulin. Using this scheme, the multiple stepwise regression for UV Ep concentration was improved by the inclusion of amniotic fluid insulin as a third step $\left(\mathrm{F}_{2,38}\right.$ to enter $=7.5, p<0.01$, multiple $\left.r^{2}=0.52, p<0.0001\right)$. Al- though amniotic fluid C-peptide correlated significantly with UV Ep concentration using simple linear regression, substitution of C-peptide for amniotic fluid insulin in the latter's place as the third step in the forced stepwise regressions made no significant contribution to fetal Ep.

\section{Discussion}

In the present study antepartum mean maternal $\mathrm{HbA}_{1 \mathrm{C}}$ values measured during the last month of pregnancy in Type 1 diabetic pregnancies were found to correlate with fetal Ep levels at delivery. Using a prospectively developed statistical pathway model with stepwise multiple regression, we suggest that maternal glycaemia acting
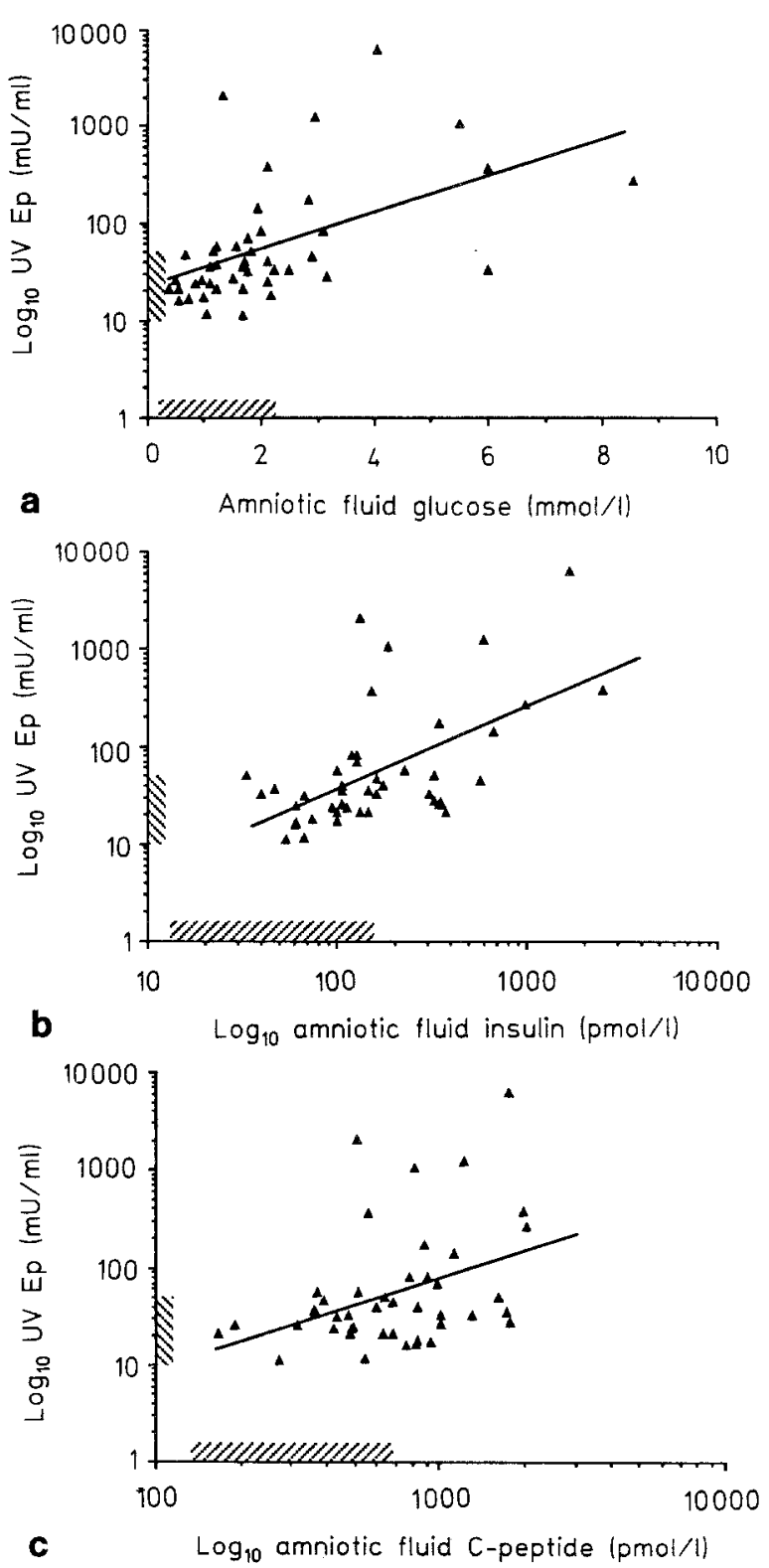

Fig.3a-c. Correlation of umbilical vein erythropoietin with: a amniotic fluid glucose $\left(r=0.51, \quad p<0.001, \quad \log _{10} \mathrm{y}=0.19 \mathrm{x}+1.35\right.$, $\left.\mathrm{SE}_{\text {est }}=0.54\right) ; \quad b$ amniotic fluid insulin $(r=0.56, \quad p<0.0001$, $\left.\log _{10} \mathrm{y}=0.83 \log _{10} \mathrm{x}-0.107, \mathrm{SE}_{\mathrm{est}}=0.52\right)$; and camniotic fluid C-peptide $\left(r=0.39, p<0.01, \log _{10} \mathrm{y}=0.94 \log _{10} \mathrm{X}-0.90, \mathrm{SE}_{\mathrm{est}}=0.57\right)$ at delivery in 44 offspring insulin-treated diabetic subjects. The shaded areas on each axis represent the range of values for the 23 control subjects 
through fetal metabolic perturbations of glucose and/or insulin may have direct influence on antepartum fetal oxygenation. This speculation has important implications for the management of maternal glycaemia during diabetic pregnancy.

Previous reports in the human have demonstrated a high incidence of late gestation stillbirths [1,2], antepartum $[27,28]$ and intrapartum fetal distress [5, 29], and neonatal polycythaemia [30] in diabetic pregnancy. Previously we have reported that fetuses of diabetic mothers have increased levels of plasma Ep concentration at delivery $[3,14]$, while others have documented direct and indirect evidence for increased fetal erythropoiesis [31,32]. More recent reports have found that antepartum maternal hyperglycaemia in diabetic pregnancy is associated with impaired uterine blood flow [33].

Moreover, in animal studies using chronically catheterized fetal sheep, direct associations have been found between fetal oxygenation and perturbations of maternal and fetal biochemical and hormonal factors associated with poorly controlled diabetes. In a study by Philipps et al. the infusion of glucose to the fetus resulted in a fall in oxygen content accompanied by a rise in fetal oxygen consumption [22]. In a separate report, these authors observed a rise in fetal plasma Ep concentration in glucoseinfused sheep fetuses in which arterial blood oxygen content had fallen by $40 \%$ or more [9]. Milley et al. performed similar studies with fetal insulin infusions and reported a fall in fetal arterial oxygen content and a rise in oxygen consumption [23]. Finally, Mimouni et al. have shown that acute maternal hyperketonaemia is associated with fetal hypoxaemia secondary to reductions in uterine blood flow in sheep [34].

The principle finding in the present study was the highly significant relationship between maternal $\mathrm{HbA}_{1 \mathrm{C}}$ and fetal Ep concentration in the group of Type 1 diabetic pregnancies. Furthermore, this relationship was also evident in the subgroup of these pregnancies in which other risk factors associated with fetal hypoxaemia were eliminated. We therefore suggest that it is maternal hyperglycaemia per se which is primarily associated with fetal hypoxaemia. Our finding that fetal Ep levels correlated best with mean maternal $\mathrm{HbA}_{1 \mathrm{C}}$ values during the month preceding delivery is consistent with the hypothesis that maternal hyperglycaemia is temporally related to fetal hypoxaemia in diabetic pregnancy. Whether maternal glucose and fetal Ep concentration are significantly correlated earlier in pregnancy or in other situations in which the fetus may be hypoxaemic requires prospective examination in sequential antepartum studies utilizing cordocentesis and/or amniocentesis. Our previous inability to detect an association between maternal $\mathrm{HbA}_{1 C}$ and UV Ep concentration may have been due to inclusion of pregnancies in which the fetus experienced labour, to differences in the degree of glucose control, and/or to population differences [3].

The mechanism for the relationship between maternal hyperglycaemia and fetal hypoxaemia was sought by studying the associations of fetal UV Ep concentration with several intermediary indicators of fetal metabolism which have been correlated with maternal glycaemia: amniotic fluid concentration of glucose, insulin, and C-pep- tide. We found in fetuses of diabetic mothers that fetal amniotic fluid glucose concentration alone (using simple regression) or in conjunction with maternal $\mathrm{HbA}_{1 \mathrm{C}}$ (using forced stepwise regression) correlated with UV plasma Ep concentration. This suggests that fetal hyperglycaemia itself is an additional causal factor in the pathophysiologic cascade leading to fetal hypoxaemia in diabetic pregnancies.

When amniotic fluid insulin was examined as the next step in our pathway model, we found that it too correlated significantly with UV Ep concentration in the simple regressions $(p<0.01)$. More importantly, when amniotic fluid insulin was added after maternal $\mathrm{HbA}_{1 \mathrm{C}}$ and amniotic fluid glucose as the third and final step in the forced regressions, it made a further significant contribution to UV Ep. This raises the possibility that insulin exerts an independent effect on fetal oxygenation beyond that of maternal and fetal glycaemia.

When amniotic fluid C-peptide was substituted for fetal insulin in these stepwise multiple regressions with UV and amniotic fluid Ep, it did not contribute significantly. This may have been due to the inherent lack of a direct physiological effect for C-peptide.

The lack of a difference in umbilical arterial $\mathrm{pO}_{2}$ tension between the diabetic and control groups may have been due to a differential effect of the anaesthetic delivery in the two groups, or merely reflect similar arterial oxygen tensions in the presence of accelerated tissue metabolism and increased oxygen requirements. The significant respiratory acidaemia observed in the group of fetuses of diabetic mothers is consistent with the latter of the two possibilities. This speculation is supported by findings of respiratory acidaemia reported in chronically hyperglycaemic and hyperinsulinaemic fetal sheep $[22,35]$, but this has not been previously reported in human fetuses.

The finding of a higher mean UV Hb in the group of fetuses of diabetic mothers is consistent with the mean higher Ep level observed in this group. This finding has not been reported previously in fetuses of diabetic mothers. Since the increase in $\mathrm{Hb}$ level would have been due to stimulation of erythropoiesis occurring weeks earlier, the lack of a significant relationship of UV Hb concentration and Ep concentration is not unexpected. The higher $\mathrm{Hb}$ concentration in the group of fetuses of diabetic mothers would result in greater oxygen carrying capacity to fuel increased tissue metabolism needs.

In summary, in the present study of diabetic pregnancies we have demonstrated a strong direct association between antepartum maternal $\mathrm{HbA}_{1 \mathrm{C}}$ level and fetal $\mathrm{Ep}$ concentrations in umbilical plasma at delivery. When analysed using the prospectively developed statistical pathway model presented in Figure 1, the data support our hypothesis that maternal glycaemia influences fetal oxygenation through intermediary fetal metabolic pathways. This we infer from the significant, independent contributions of fetal glucose and fetal insulin concentration in the stepwise multiple regression analyses. Based on studies in fetal animals, it appears that fetal hyperglycaemia and hyperinsulinaemia result in increased fetal oxygen utilization through incompletely elucidated biochemical means. Our results in humans suggest that the maintenance of maternal normogly- 
caemia may be an important clinical factor in avoiding the complications associated with fetal hypoxaemia in diabetic pregnancies.

Acknowledgements. This study was supported by grants from the March of Dimes Birth Defects Foundation, the National Institute of Child Health and Human Development (HD 11343), the National Heart, Lung and Blood Institute (NHLBI 22469), the Rhode Island Hospital research fund, and the Nordisk Insulin research fund. The authors wish to acknowledge the assistance of Ms. P Kuparinen, R.N., for her careful data collection and record keeping, of Mrs. K Petzold and Ms. D DeManincor for expert technical assistance, and of Mrs. L Gold for careful editing and secretarial assistance.

\section{References}

1. Pedersen J (1977) The pregnant diabetic and her newborn, 2nd edn. Munkgaard, Copenhagen

2. Persson B, Bjork O, Hansson U, Stangenberg M (1984) Neonatal management 1983. In: Sutherland HW, Stowers JM (eds) Carbohydrate metabolism in pregnancy and the newborn. Churchill Livingstone, New York, pp 133-143

3. Widness JA, Susa JB, Garcia JF, Singer DB, Seghal P, Oh W, Schwartz R, Schwartz HC (1981) Increased erythropoiesis and elevated erythropoietin in infants born to diabetic mothers and in hyperinsulinemic rhesus fetuses. J Clin Invest 67: 637-642

4. Madsen H (1986) Fetal oxygenation in diabetic pregnancy: with special reference to maternal blood oxygen affinity and its effectors. Danish Medical Bull 33: 64-74

5. Mimouni F, Miodovnik M, Siddiqi TA, Khoury J, Tsang RC (1988) Perinatal asphyxia in infants of insulin-dependent diabetic mothers. J Pediatr 113: 345-353

6. Widness JA, Clemons GK, Garcia FJ, Oh W, Schwartz R (1984) Increased immunoreactive erythropoietin in cord serum after labor. Am J Obstet Gynecol 148: 194-197

7. Nathan DM, Singer DE, Hurxthal K, Goodson JD (1984) The clinical information value of the glycosylated hemoglobin assay. N Engl J Med 310: 341-346

8. Zanjani ED, Gordon AS (1971) Erythropoietin production and utilization in fetal goats and sheep. Israel J Med Sci 7: 850-856

9. Widness JA, Garcia JF, Clemons GK, Cavalieri RL, Susa JB, Teramo KA, Schwartz R (1986) Temporal response of immunoreactive erythropoietin to acute hypoxemia in the sheep fetus. Pediatr Res 20: 15-19

10. Philipps AF, Widness JA, Garcia JF, Raye J, Schwartz R (1982) Erythropoietin elevation in the chronically hyperglycemic fetal lamb. Proc Soc Exp Biol Med 170: 42-47

11. Spellacy WN, Buhi WC, Bradley B, Holsinger KK (1973) Maternal, fetal and amniotic fluid levels of glucose, insulin and growth hormone. Obstet Gynecol 41: 323-331

12. Seeds AE, Leung LS, Tabor MW, Russell PT (1979) Changes in amniotic fluid glucose, $\beta$-hydroxy-butyrate, glycerol, and lactate concentration in diabetic pregnancy. Am J Obstet Gynecol 135: 887-895

13. Weiss PAM, Pürstner P, Winter RR, Lichtenegger W (1984) Insulin levels in amniotic fluid of normal and abnormal pregnancies. Obstet Gynecol 63:371-375

14. Teramo KA, Widness JA, Clemons GK, Voutilainen P, McKinlay S, Schwartz R (1987) Amniotic fluid erythropoietin correlates with umbilical plasma erythropoietin in normal and abnormal pregnancy. Obstet Gynecol 69:710-716

15. Stenman U-H, Pesonen K, Ylinen K, Huhtala M-L, Teramo K (1984) Rapid chromatographic quantification of glycosylated haemoglobin. J Chromatogr 297: 327-332

16. Fineberg SE, Galloway JA, Fineberg NS, Rathburn MJ, Hufferd $S$ (1983) Immunogenicity of recombinant DNA human insulin. Diabetologia 25: 465-469
17. Garcia JF, Ebbe SN, Hollander L, Cutting HO (1982) Radioimmunoassay of erythropoietin: circulating levels in normal and polycythemic human beings. J Lab Clin Med 99: 624-635

18. Jelkmann W (1986) Renal erythropoietin: properties and production. Resp Physiol 104: 139-215

19. Emmanouel DS, Goldwasser E, Katz AI (1984) Metabolism of pure erythropoietin in the rat. Am J Physiol 247: F168-F176

20. Embury SH, Garcia JF, Mohandas N, Pannathur-Das R, Clark MR (1984) Effects of oxygen inhalation on endogenous erythropoietin kinetics, erythropoiesis, and properties of blood cells in sickle-cell anemia. N Engl J Med 311:291-295

21. Mladenovic J, Eschbach JW, Koup JR, Garcia JF, Adamson JW (1985) Erythropoietin kinetics in normal and uremic sheep. J Lab Clin Med 105: 659-663

22. Philipps AF, Porte PJ, Stabinsky S, Rosenkrantz TS, Raye JR (1984) Effects of chronic fetal hyperglycemia upon oxygen consumption in the ovine uterus and conceptus. J Clin Invest 74: 279-286

23. Milley JR, Rosenberg AA, Philipps AF, Molteni RA, Jones MD, Simmons MA (1984) The effect of insulin on ovine fetal oxygen extraction. Am J Obstet Gynecol 149: 673-678

24. Metzger BE, Freinkel N (1979) Pregnancy as a tissue culture experience: the critical implications of maternal metabolism for fetal development. In: Pregnancy metabolism, diabetes and the fetus. Excerpta Medica, Amsterdam, pp 3-23 (CIBA Foundation Symposium No 63)

25. Weiner BJ (1971) Statistical principles in experimental design. 2nd edn. McGraw-Hill, New York, pp 487-490

26. Thomas RM, Canning CE, Cotes PM, Linch DC, Rodeck CH, Rossiter CE, Huehns ER (1983) Erythropoietin and cord blood haemoglobin in the regulation of human fetal erythropoiesis. $\mathrm{Br}$ J Obstet Gynaecol 90: 695-800

27. Kariniemi V, Forss M, Siegberg R, Ämmälä P (1983) Reduced short-term variability of fetal heart rate in association with maternal hyperglycemia during pregnancy in insulin-dependent diabetic women. Am J Obstet Gynecol 147: 793-794

28. Teramo KA, Ämmälä P, Ylinen K, Raivio KO (1983) Pathologic fetal heart rate associated with poor metabolic control in diabetic pregnancies. Obstet Gynecol 61: 559-565

29. Olofsson P, Ingemarsson I, Solum T (1986) Fetal distress during labour in diabetic pregnancy. Br J Obstet Gynaecol 93: 10671071

30. Mimouni F, Miodovnik M, Siddiqi TA, Butler JB, Holdroyde J, Tsang RC (1986) Neonatal polycythemia in infants of insulin-dependent diabetic mothers. Obstet Gynecol 68: 370-372

31. Naeye RL (1965) Infants of diabetic mothers: a quantitative, morphology study. Pediatrics 35: 980-988

32. Stevenson DK, Bartoletti AL, Ostrander CR, Johnson JD (1976) Pulmonary excretion of $\mathrm{CO}$ in the human infant as an index of bilirubin production. II Infants of diabetic mothers. J Pediatr 94: 956-958

33. Nylund L, Lunell N-O, Lewander R, Persson B, Sarby B (1982) Uteroplacental blood flow in diabetic pregnancy: measurements with indium $113 \mathrm{~m}$ and a computer-linked gamma camera. Am J Obstet Gynecol 144: 298-302

34. Mimouni F, Skillman C, Harrington DJ (1986) Effects of maternal hyperglycemia and ketoacidemia on the pregnant ewe and fetus. Am J Obstet Gynecol 154:394-401

35. Stonestreet BS, Goldstein M, Oh W, Widness JA (1989) Effects of prolonged hyperinsulinemia on erythropoiesis in fetal sheep. Am J Physiol 257: R 1199-R 1204

Received: 2 October 1989

and in revised form: 29 January 1990

Dr. J.A. Widness

Department of Pediatrics

University of Iowa

Iowa City, IA 52242

USA 